\title{
Using CIPP to Conduct Evaluation of Exhibition Practice Teaching
}

\author{
Hongxia $\mathrm{Wu}^{1, \mathrm{a}}$ \\ ${ }^{1}$ Beijing College Finance and Commerce, Beijing, China \\ awuhx@bjczy.edu.cn
}

\section{Keywords: Exhibition practice teaching; Educational reform; CIPP model; Practical teaching}

\begin{abstract}
In order to promote the reform of the practical education of Exhibition Major, the basic evaluation framework of practical teaching was established according to the four basic steps of the CIPP model. CIPP model was used to carry out the evaluation of practice teaching in conventions and exhibitions. This method can effectively improve the teaching quality of MICE practice courses and at the same time help teachers to continuously improve teaching. When the researchers use the CIPP model, they should pay attention to changing the evaluation of the convention and practice teaching, carefully selecting the appraisers to exert the improvement of evaluation and development functions, and organizing the evaluation process under the development of the concept of evaluation.
\end{abstract}

\section{Introduction}

For the exhibition professional teaching, the practical teaching mode is actively and effectively carried out in various colleges and universities. It has played a good role in the exhibition professional teaching, training theory and practical ability of MICE professionals [1]. However, no consensus has been reached in the evaluation of practical teaching evaluation. The evaluation of teaching in a comprehensive practice is still weak. Although MICE practice teaching has been carried out for many years, the theoretical research on practical teaching evaluation is still very few. Therefore, it is of certain value to strengthen the research on the evaluation of practical teaching. Establishing and perfecting the project-oriented teaching evaluation system of the exhibition professional is one of the important links in the professional education of higher vocational education to ensure the quality of practical teaching and realize the goal of personnel training.

In 2012, the exhibition specialization of our institute started the curriculum reform of Project Leading Teaching in our school. The teaching effect has also been recognized by many people, but the course has not been evaluated well. Establishing a scientific evaluation system that conforms to the teaching principles of the practical courses of professional exhibitions and professional exhibitions and effectively exerting the guiding role of the evaluation mechanism in the entire curriculum implementation process is a problem that needs to be solved urgently in the project curriculum reform of higher vocational education. The project teaching reform and the actual characteristics of the curriculum were combined to construct evaluation system with CIPP.

\section{CIPP Model}

The Background and Content of CIPP Model. The American scholar Stufflebeam (D.L.) proposed the CIPP evaluation model based on the reflection of Taylor's behavioral target model in 1965 [2]. The evaluation model was adopted by the United States through the America's Elementary and Secondary Education Act (ESEA), the federal government's request for assessment methods adopted by the states, and applied to the evaluation of other items of education. The CIPP model is also called decision-oriented evaluation model. The CIPP evaluation model consists of the first letters of the four evaluation activities: (1) Context evaluation, (2) Input evaluation, (3) Process evaluation, (4) Product evaluation, referred to as CIPP evaluation model. The CIPP evaluation model takes into account the selection of objects and their rationality, overcomes the shortcomings of the beginning and the evaluation model, and is suitable for the evaluation of college courses. The specific content of the CIPP are as follows. 


\section{Context Evaluation}

This is the first stage of the evaluation activity and the evaluation of the target itself. The purpose of this phase of setting is to focus on the objective rationality of the target behavior pattern and examine the value and correctness of the target.

\section{Input Evaluation}

This is the second stage of the evaluation activity and it evaluates the implementation of the goals. Before the implementation of the activity, it is necessary to plan activities, such as the conditions, steps, and methods required for the activities. This stage is the feasibility of the implementation of the textual research and the implementation of the plan.

\section{Process Evaluation}

This is the third stage of the evaluation activity and the evaluation of the implementation process of the activity plan. Whether the envisaged goal is correct, the target's implementation process, and whether the plan can be implemented as scheduled in actual activities. The inspection is the main task of this evaluation stage.

\section{Product Evaluation}

It is the fourth stage of the evaluation activity and it is an evaluation of the achievement of the goal. This stage not only needs to summarize the experience of the final evaluation of the results of the activities, but also to find out the problems of the entire activity to support the smooth development of follow-up activities.

Based on the above evaluation process, combined with the teaching content of the MICE practice course, an evaluation model of the MICE practice course was obtained as follows.

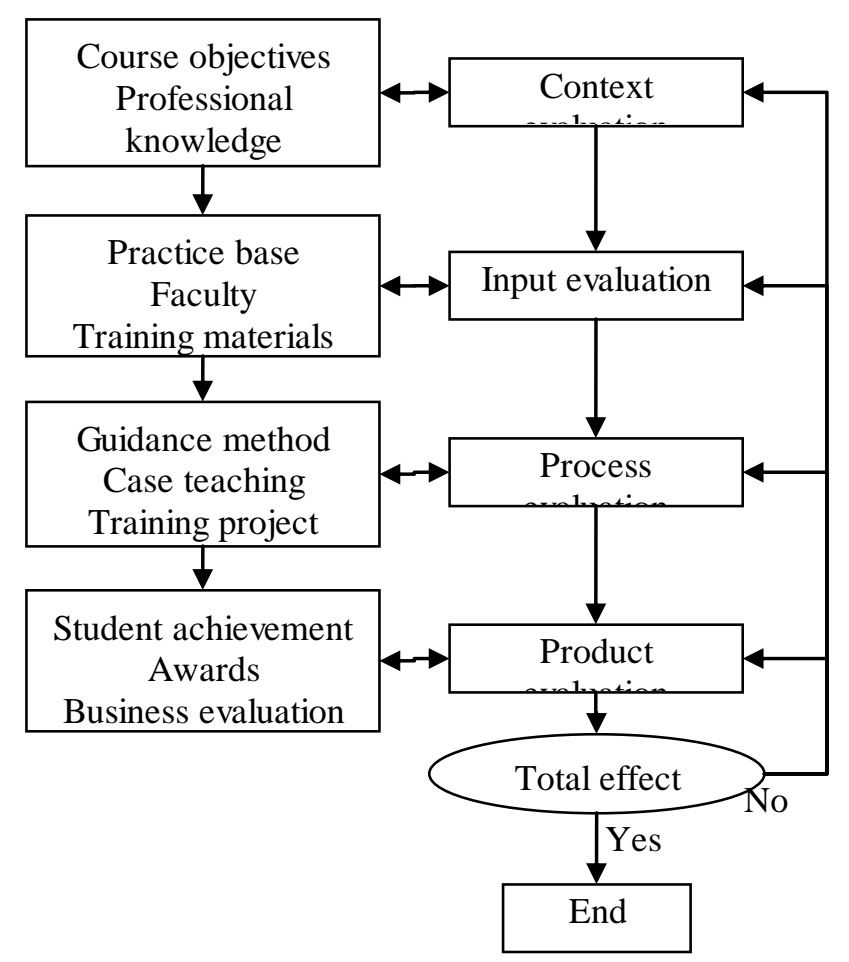

Figure 1. Finite Exhibition practice evaluation based on CIPP

The various stages of the CIPP evaluation model have distinctive features. The particular characteristics are overall nature, process, and feedback. This model really puts the activity of evaluation through every link in the entire course. The training course activity is linked. Background assessment corresponds to the determination of training needs and the determination of training objectives. Input evaluation corresponds to the steps of determining the course and designing and planning the course. Process evaluation corresponds to the step of executing the course [3].

The Status Quo of Practice Teaching Evaluation of Exhibition Majors. At present, the subject of the evaluation of the professionalism of both the undergraduate teaching and the vocational education in 
China's exhibition industry is relatively single. Most of the teachers evaluate the effectiveness of practical teaching based on attendance, the students' classroom performance, the basic performance of practice, practice reports, etc. The content of the evaluation cannot fully reflect the effect of practical teaching [4]. Basically, teachers still occupy a dominant position, lack clear evaluation criteria, and do not have students participate in the whole process of internship evaluation, evaluation of practical projects, and professional evaluation of corporate teachers. Due to the single subject of evaluation, incomplete evaluation content, and lack of evaluation criteria, the lack of evaluation theory of practical teaching and learning in practice does not reflect the real effect of practical teaching.

Applicability of CIPP Model to Practice Teaching of MICE Major. According to the above analysis, the CIPP model is suitable for educational activities and project evaluation, and has applicability for the evaluation of the quality of MICE practice teaching. The specific content is as follows.

The CIPP evaluation model is centered on decision making. It is believed that the most important purpose of evaluation is not certification but improvement. The model can use a same process to achieve practical teaching evaluation under the conditions of different types of practice, teaching investment and teaching forms. Therefore, it is theoretically suitable for most course teaching evaluation.

In the past, the evaluation of the practice teaching is only based on the students' achievements or how many awards they received. The teaching evaluation mainly focused on the results but did not attach importance to the evaluation of the goals or processes. The evaluation of the practice teaching in the CIPP mode needs to change the evaluation purpose and force the evaluation participants to pay attention to the goal, the teaching design, the teaching process, and the effect of the teaching.

\section{Practical Teaching Evaluation System Based on CIPP Mode}

The exhibition practice curriculum includes teaching goals; teaching content; teaching methods; teaching bases; faculty; supporting projects; teaching achievements and other aspects [5]. The CIPP model was used to carry out the evaluation of the quality of MICE professional practice in four stages. They were the evaluation of the practice objectives of MICE, the appraisal of the practical teaching plan of MICE, the evaluation of the professional practice of MICE, and the evaluation of professional practice teaching of MICE.

Evaluate the Professional Teaching Objectives of MICE. In this stage, we must conduct a diagnostic evaluation of the teaching objectives for exhibition major. Under the traditional view of teaching, the setting of teaching objectives mainly emphasizes the improvement of students' knowledge and skill levels, and is guided by enhanced skills training. Although this goal also advocates ensuring the subjectivity of students, this subjectivity only serves as the subjective initiative and initiative of receptivity and does not have the independence and creativity as the forming subject.

\section{Combine the Skills, Processes and Professional Attitudes}

The training objective of the professional exhibition and exhibition professional is to train skilled talents who can better engage in the work of management and service of exhibition companies. Therefore, when examining the teaching objectives set by the teachers, in addition to the knowledge and skills objectives of the convention and exhibition, it is also necessary to examine whether they are equal to the goals of other dimensions and to make the goals form a unified whole.

\section{Hierarchical and Targeted Goals for Student Development}

The professional practice of the convention and exhibition education should be oriented toward all students. The goal reflected is that most students can achieve their goals through hard work. At the same time, it is necessary to set targets in a hierarchical manner and enhance students' selectivity, which should be consistent with the characteristics of the teaching content and the actual level of the students. In the learning process, students with different interests and levels should have different development.

Evaluate MICE Professional Practice Teaching Plan. This stage requires the analysis and judgment of the scientific nature of the exhibition professional practice teaching program. After determining the professional teaching objectives of the convention and exhibition professional, whether or not it can be implemented and how it is implemented is reflected in the professional teaching plan of 
the convention and exhibition (teaching plan). It is a pre-design for carrying out the professional teaching activities of exhibitions. It is necessary to understand students, interpret teaching contents, select appropriate teaching methods.

\section{Examine the Correspondence between Target Expression and Process}

This process needs to evaluate the arrangements of the professional teaching process of the convention and exhibition profession, and whether each link and method is carried out around the set goals. The basic factors of teaching, whether the processing of the relationship between teachers, students, teaching content, teaching methods, and teaching environment is to serve the goal.

\section{Examine the Feasibility of Practical Teaching Program Implementation}

The practical teaching plan is the design of the future teaching activities. It is the teacher's expectations and whether it can realize the need for further research by experts and experienced personnel. Therefore, this stage of evaluation should evaluate its expected feasibility, consider the teaching plan designed by the teacher to identify and provide the necessary conditions for the set teaching objectives, and the appropriateness and operability of the teaching strategies adopted.

Evaluate the Process of Practice Teaching Activities. This stage is the evaluation of the implementation of the professional and practical teaching programs of the exhibition. The teaching plan is only a plan and a plan. It depends on actual teaching activities. This is also what we often say. In all teaching sessions, class is the central link. This stage of evaluation has obvious dynamics. In the face of MICE professional practice teaching relationship, there are many uncertainties and unintended effects and effects of teaching objectives.

\section{Examine Teachers' Effective Teaching Behavior}

The choice of teaching content is in line with the students' physical and mental characteristics and development needs. It fully considers the individual differences of students and respects the student's right to choose so that students can benefit equally in the process of participating. The organization of MICE professional practice teaching needs to change roles, share experiences with students, become partners in student learning process, respect student emotions and experiences, guide and encourage students to learn independently, give play to students' imagination and creativity, and explore and improve te level of practice of convention and exhibition.

\section{Examine Students' Learning Status}

The students' learning status is mainly manifested in the interest and attitude to learning and profession, and whether they have positivity and initiative in learning. The important observation point is the degree of students' participation in the practice of convention and exhibition. On the one hand, the breadth of participation is whether all students can be interested in activities. On the other hand, the depth of participation is the active participation in the understanding of the teaching process and the purpose and role of the activities.

Evaluate the Professional Teaching Achievements of MICE. This stage is the evaluation of the results of the implementation of practical teaching programs. Evaluation of practical teaching results is a comprehensive examination of the quality of classroom teaching, but also to implement the evaluation of the improved functions, and provide decision-making basis for the design of new practical teaching programs. Examine the achievement of teaching goals. To determine which goals were successfully achieved, and to find unachievable goals so as to analyze the reason why the preset goals could not be reached. Some of the goals have not been achieved because the target design is not in line with the actual situation. It is difficult to achieve in the practical teaching process. Some of the goals have not been implemented because of the organizational design of the implementation process of practical teaching. Examining the effectiveness of the goal realization process

The results of practical teaching mainly examine the results achieved by the goal, and effectiveness must reflect efficiency. That is, the relationship between input and output of goals is achieved. Here, the differences between the time and effort invested by teachers and students and the expected situations must be examined here. 


\section{Evaluating the Unintended Effect of Practical Teaching Activities}

The CIPP model is used to assess the implementation process and results of the evaluation of the exhibition professional practice teaching from the goal setting to the goal. It has always been centered on the goal and is an expected activity. Practical teaching activities are creative activities. Many unintended effects appear in the teaching process. They are also called side effects and have a great impact on students but are not within the goal. Based on the above, a part plan for CIPP of exhibition practice courses is as Table 1 .

Table 1 Evaluation plan of practice course under CIPP mode

\begin{tabular}{|c|l|}
\hline CIPP & \multicolumn{1}{|c|}{ Questions related to course evaluation } \\
\hline \multirow{3}{*}{ Context evaluation } & $\begin{array}{l}\text { What is the goal of the course? } \\
\text { What is the content of the course? } \\
\text { Practical teaching content of different courses? }\end{array}$ \\
\hline \multirow{3}{*}{ Input evaluation } & $\begin{array}{l}\text { Is the teaching material most useful? } \\
\text { Is the teaching staff sufficient? } \\
\text { Is the teaching base perfect? } \\
\text { Adequate funding for the course? }\end{array}$ \\
\hline \multirow{3}{*}{ Process evaluation } & $\begin{array}{l}\text { How do students learn the MICE practice course? } \\
\text { Is there strong support from the school? } \\
\text { What are the difficulties? }\end{array}$ \\
\hline \multirow{3}{*}{ Product evaluation } & $\begin{array}{l}\text { Whether to achieve the curriculum goals? } \\
\text { How is student evaluation and satisfaction? } \\
\text { How is teacher evaluation? } \\
\text { How is corporate feedback and evaluation? }\end{array}$ \\
\hline
\end{tabular}

\section{Conclusion}

CIPP evaluation model is an open evaluation method. It focuses on process evaluation and the combination of evaluation process and teaching, emphasizes evaluation feedback, and advocates the use of evaluation to promote teaching reform and development. The application of the CIPP model to the construction of the professional evaluation system of exhibition professional practice can promote the teaching reform and the change from the result evaluation, improve the quality of practical teaching, students' practical ability, and better training high-tech technical talents who work in the management of exhibition companies, service operations, etc.

\section{References}

[1] Shifeng Qian, Construction and Reflection of Diversified Progressive Practice Teaching System for Higher Vocational MICE Majors, Chinese Vocational and Technical Education, (2014) No.32, p.44-47.

[2] Stufllebeam DL. The CIPP model for evaluation (Kluwer Academic Publishers, Boston 2003).

[3] Li Jun, Zhang Junling, Li Chun, Implementation and evaluation on CIPP evaluation pattern in project teaching in vocational colleges, Chinese Nurfing Research, Vol. 27 (2013) No.8, p.3292-3294.

[4] Dianwei Zhang, Weijie Liu, Study on Evaluation Index System of Practical Teaching in Colleges and Universities Based on CIPP Mode, China Adult Education, (2016) No.9, p.110-113.

[5] Hongxia Wu, Discussion on the Practice Teaching Reform Mode of Exhibition Professionals, China Market, (2017) No.1, p.237-238. 